\title{
Beneficial insect community of Moroccan citrus groves: assessment of their potential to enhance biocontrol services
}

\author{
Moulay Chrif Smaili ${ }^{1 *}$, Abdelmalek Boutaleb-Joutei ${ }^{2}$ and Abdelaali Blenzar ${ }^{3}$
}

\begin{abstract}
In citrus groves, beneficial insects that reduce abundance of pests are considered a key component of integrated pest management strategies. The aim of this article was to assess the biodiversity of parasitoids and predators in citrus orchards in Moroccoto facilitate future investigations on their potential as biocontrol agents. Data of 105 citrus beneficial insects were gathered and summarized in a data matrix. Variables such nature, target pests, type, establishment, and efficacy were assessed. More than two-thirds of parasitoids and predators species identified in citrus groves of Morocco (105 species) are native (> 70\%). Both groups represent only a small fraction of the introduced species. The mostly attack armored scale insects (Diaspididae) and aphids (Aphididae). The ladybeetle Rodolia cardinalis (Mulsant) (Coleoptera: Coccinellidae) is the first beneficial species introduced in 1921 to the Moroccan citrus orchards to control the cottony cushion scale Icerya purchasi (Maskell) (Hemiptera: Monophlebidae). Major introductions of these parasitoids and predators were carried out during the ninetieth to control the main citrus pests whereas they were accidentally introduced. These purposely introduced species are mainly Aphelinidae, Encyrtidae, Eulophidae, Coccinellidae, and Phytoseiidae. Whereas a high proportion of the introduced beneficial insects was established and no species have been reported to be harmful to this date. Considering only the introduced species used in classical biological control context, about 20 and $40 \%$ of them are considered as effective or partially effective, respectively.
\end{abstract}

Keywords: Citrus, Biological control, Parasitoids, Predators, Species diversity, Morocco

\section{Background}

In Morocco, the citrus industry plays a very important socio-economic role in the national economy with an area of about 126,600 ha and a production of about 2.3 million tons (ASPAM 2018). This sector provides an important source of foreign currency per year and generates significant effects in employment through the creation about more than 35 million working days a year in orchards and at the packaging and processing industry and other activities related to citrus industry. In Morocco, citrus trees are infested by several

\footnotetext{
*Correspondence: csmaili@yahoo.fr

${ }^{1}$ Reasearch Unit of Plant Protection, Regional Center for Agricultural Research of Kenitra, National Agricultural Research Institute, Box: 257, Kenitra, Morocco Full list of author information is available at the end of the article
}

phytophagous insects, mites, and snails, which significantly affect citrus yield quality and quantity by damaging leaves, young shoots, twigs, and fruits (Abbassi 2010; Smaili et al. 2001; Mazih 2015; Smaili 2017). Therefore, a need to develop new approaches to control these pests, using environment friendly approaches, as an alternative to chemical control is becoming a necessity for citrus producers. In the past, the control methods of the main citrus pests were applied with a few considerations of the abundance of beneficial insects and their impact on harmful pests in the Moroccan research studies (Smaili 2009; Smaili et al. 2014). However, now many reasons have greatly induced Moroccan citrus producers to enhance the IPM strategy: (i) the outbreak of new citrus pests problems such as whiteflies, 
leafhoppers, ants, and thrips (Smaili and Benyahia 2018; Smaili et al. 2018); (ii) the new requirements of importers and local market, related to ship agreed quality of citrus fruits; (iii) the exporting companies have a certified orchards with the standards and requirements of importing the fresh citrus fruit with new rigourous control requirements (e.g., China and USA requirements for citrus exporting); (iv) available effective insecticides and acaricides on control citrus pests are probably not be commercialized in the near future in Morocco (e.g., Chlorpyrifos-ethyl); (v) the need of the citrus producers for the exploration possibility for large-scale exports to new foreign markets. Indeed, new management practices such as good plant protection practices, integrated pest management strategy, classical biological control, conservative biological control, and taken into account the side effects of theses pesticides applied on citrus trees on natural enemies. In addition, worldwide, many effective species of parasitoids and predators have been found out and many species are currently available in the market. Almost 250 species of invertebrate biological control agents are used to enhance biological control and pest management worldwide (Van Lenteren et al. 2018).

Several parasitoids and predators have been reported in Moroccan citrus groves and some of them play an important role in maintaining some pests under economic threshold levels (Abbassi 1990, 2010; Smaili et al. 2010, 2013, 2014). Most of them are native species while some have been accidentally introduced or deliberately released to control certain pests. The use of natural enemies in Morocco is very old especially in citrus orchards (Smirnoff 1954, 1956; Delucchi 1963; Delucchi and Merle 1963). The first introduction of the parasitoids and/or predators to the Moroccan citrus groves (e.g., coccinellid beetles and aphelinids wasps) started almost a century ago (Smirnoff 1956; Bennassy and Euverte 1967; Euverte 1967 and EPPO 2011) already in 1921, the vedalia beetle Rodolia cardinalis (Mulsant, 1850) (Coleoptera: Coccinellidae) was introduced to the Moroccan citrus groves to control the cottony cushion scale Icerya purchasi (Maskell, 1878) (Hemiptera: Monophlebidae). The coccinellid Cryptolaemus montrouzieri (Mulsant, 1853) was also introduced to citrus groves during 1933 to control the citrus mealybug Planococcus citri (Risso, 1813) (Hemiptera: Pseudococcidae). In 1944, the coccinellid Rhyzobius lophanthae (Blaisdell, 1892) was introduced to control diaspines scale in citrus trees (Smirnoff 1956). During the 60s, the parasitoid Aphytis melinus (De Bach, 1959) and A. lepidosaphes (Compere, 1955) (Hymenoptera: Aphelinidae) were introduced to control mainly the dictyospermum scale Chrysomphalus dictyospermi (Morgan, 1889) and the California red scale Aonidiella aurantii (Maskell, 1878) (Hemiptera: Diaspididae) (Benassy and Euverte 1967; Euverte 1967 and
EPPO 2011). A great progress, related to the use of other newly introduced beneficial insects, was made during the 70s (Benassy and Euverte 1968 a, b, and Abbassi 1974, 1975a). In the 80s and 2000s period, several others parasitoids and/or predators were intentionally introduced to control main citrus pests (Abbassi 1990, 2010; Rizqi et al. 1997a, 1997b; Abdelkhalek et al. 1998; Smaili et al. 2001; Benziane 2003 and Rizqi et al. 2003).

This article aimed to assess the species richness and potential of the parasitoids and predators in citrus orchards in Morocco.

\section{Information sources}

Available information on the parasitoids and predators associated with citrus orchards in Morocco was collected using several sources: (1) direct communication with researchers and actual users of these beneficial insects for biological control; (2) peer reviewed articles; (3) database of the European and Mediterranean Plant Protection Organization (EPPO) (www.eppo.org), the Natural History Museum (NHM) (www.nhm.ac.uk), the Centre for Agriculture and Biosciences International (CABI) (www.cabi. org), and Scholar Google (www.google.com); (4) available papers published in the national proceeding, and (5) available thesis and validated scientific reports. The species data gathered from 1920 to 2018 were summarized in a data matrix including the following variables:

\section{Nature and target pests}

Beneficial insects are indigenous (native) or exogenous (introduced) and traditionally known as parasitoids and predators. Their main hosts or preys are mostly aphids (Aphididae); scale insects (armored scale Diaspididae); soft scale from Saissetia and Coccus genera (Coccidae); Pseudococcidae (genus Planoccocus); Monophlebidae (cottony cushion scale I.purchasi); whiteflies (Aleyrodidae); mites (mainly Tetranychidae); Tortricidae (mainly Cacoecimorpha genus); fruit flies (Tephritidae); Gracilariidae; citrus leaf miner (mainly Phyllocnistis citrella Stainlon (Lepidoptera: Gracillariidae). Unknown: when there is a lack of information on targeted pests of these beneficial insects.

\section{Type of introduction and establishment}

The introduction of the parasitoids and/or predators in the Moroccan citrus orchards was considered as intentionally introduced, when the species were introduced deliberately to control targeted citrus pest and accidentally introduced, and when they were introduced by an unknown manner. The status of the introduced beneficial insects was considered as established, when the species is known to be established and observed every year; not established, when the species has not 
been established and/or has not been found after their release, and unknown, when there is a lack of information on acclimatization of this beneficial insects.

\section{Efficacy}

Efficacy is considered the real impact of the parasitoids and/or predators to control one or more target pests. Five levels were proposed (adapted by Jacas et al. 2006): Effective, when the parasitoids and/or predators can reduce population of the target pest and infestation level significantly (e.g., do not exceed the economic threshold); partially effective, when the parasitoids and/or predators can control partly the population of the target pest, but with non significant reduction of infestation; low efficacy, when the beneficial species has a little impact on the population of the target pest coupled with establishment of this species once released; failure, when the parasitoids and/or predators has no effect or a very little impact on the targeted pest coupled with no real establishment (sporadic, or no establishment) of this species once released; unknown, when no information is available on the efficacy of the parasitoids and/or predators under Moroccan conditions.

\section{Additional information and assessment}

Further information on the parasitoids and/or predators in the EPPO was also provided: date reported by the EPPO; date reported in Morocco; first references to Morocco. All the above variables were estimated by a percentage (\%) with the number of the parasitoids and/ or predators reported out of the total number of all identified beneficial insects in citrus, called here as "Percentage of presence" (\%) (Jacas et al. 2006; Roy et al. 2011). For some variables (e.g., introduced species), the percentage was also calculated by the number of the parasitoids and/or predators reported over the total number of introduced beneficial insects.

\section{Results and discussion}

\section{Nature and type}

Parasitoids and predators species are fundamental for the implementation of integrated pest management (Bonsignore and Vacante 2012; Van Lenteren et al. 2018). The parasitoids and/or predators identified in citrus counted about 105 species, 76 native species, and 29 introduced species (with 72.38 and $27.61 \%$, respectively) (Tables 1 and 2). For the native species, predators (47.61\%) are more abundant than parasitoids (24.76\%). The parasitoids species belong mainly to the families: Aphelinidae, Braconidae, Encyrtidae, Eulophidae, while the predators'species belong to Coccinellidae and Phytoseiidae families. For the introduced species, their ratios are 10.47 and $17.14 \%$ for parasitoids and predators, respectively. Parasitoids and predators species belong mainly to 2 main orders: Coleoptera with 39.05\% (31.43\% for the natives and $7.62 \%$ for the introduced species) and Hymenoptera with $41.90 \%$ (24.76\% for the natives and $17.14 \%$ for the introduced). The other insect orders are still low and does not exceed $8.6 \%$. The distribution of the parasitoids and/or predators grouped by the insect families is given in Fig. 1. The rate of coccinellid species was about $34.29 \%$ (26.67\% for the natives and $7.62 \%$ for the introduced) and the aphelinid species about $16.19 \%$ (10.48\% for the natives and $5.71 \%$ for the introduced). Species belong to families Encyrtidae, Eulophidae, Braconidae, and Phytoseiidae ranged between $7.62-9.52 \%$, while the other families do not exceed $3 \%$.

\section{Target pests}

Present percentage of parasitoid and predator species in Moroccan citrus groves based on target pests are given at Fig. 2. In Moroccan citrus groves, the diaspidids and aphidids are the most targeted pests for the parasitoids and/or predators. For all parasitoids and/or predators species, targeted pests were mainly Diaspididae with $30.47 \%$ (21.90 and $8.57 \%$ for the native and introduced species, respectively) and Aphididae with $17.14 \%$ (15.23 and $1.90 \%$, respectively). This percentage did not exceed $10 \%$ for the others trophic groups. Among the introduced species, diaspidid were $(34.48 \%)$, followed by the leafminer P. citrella (17.24\%), and the white fly (17.24\%) (Fig. 3). For others, trophic group percentage of presence did not exceed $7 \%$. This is a consequence of the important richness and abundance of their main hosts, the armored scale insects and aphids, which remain the preferred target pests of many natural enemies in citrus orchards in Morocco (Abbassi 1990, 2010; Smaili et al. 2009, 2014; and Smaili 2017). In addition, arthropod pests that are exposed and not hidden and are less mobile have been more successfully controlled because their natural enemies have the capability to reach the pest (Hajek and Eilenberg 2018). Considering the introduced species only, trophic groups preferred target pests like armored scale, citrus leafminer, and white fly. This is explained in the fact that the scale insects, especially California red scale $A$. aurantii, the Chaff scale $P$. pergandii, citrus leafminer $P$. citrella, and several whiteflies species have been considered over years the most important pests in citrus orchards (Abbassi 1975b, 1975c, Abbassi 1980, Abbassi 1990, Abbassi 2010; Rizqi et al. 1997a, 1997b, 2003; Benziane 2003; Boutaleb and El Hardouni 2010and Smaili 2009, 2017).

\section{Type of introduction}

According to the types of introduction into the Moroccan citrus orchards, percentage of presence of introduced species belong to the families of Aphelinidae 


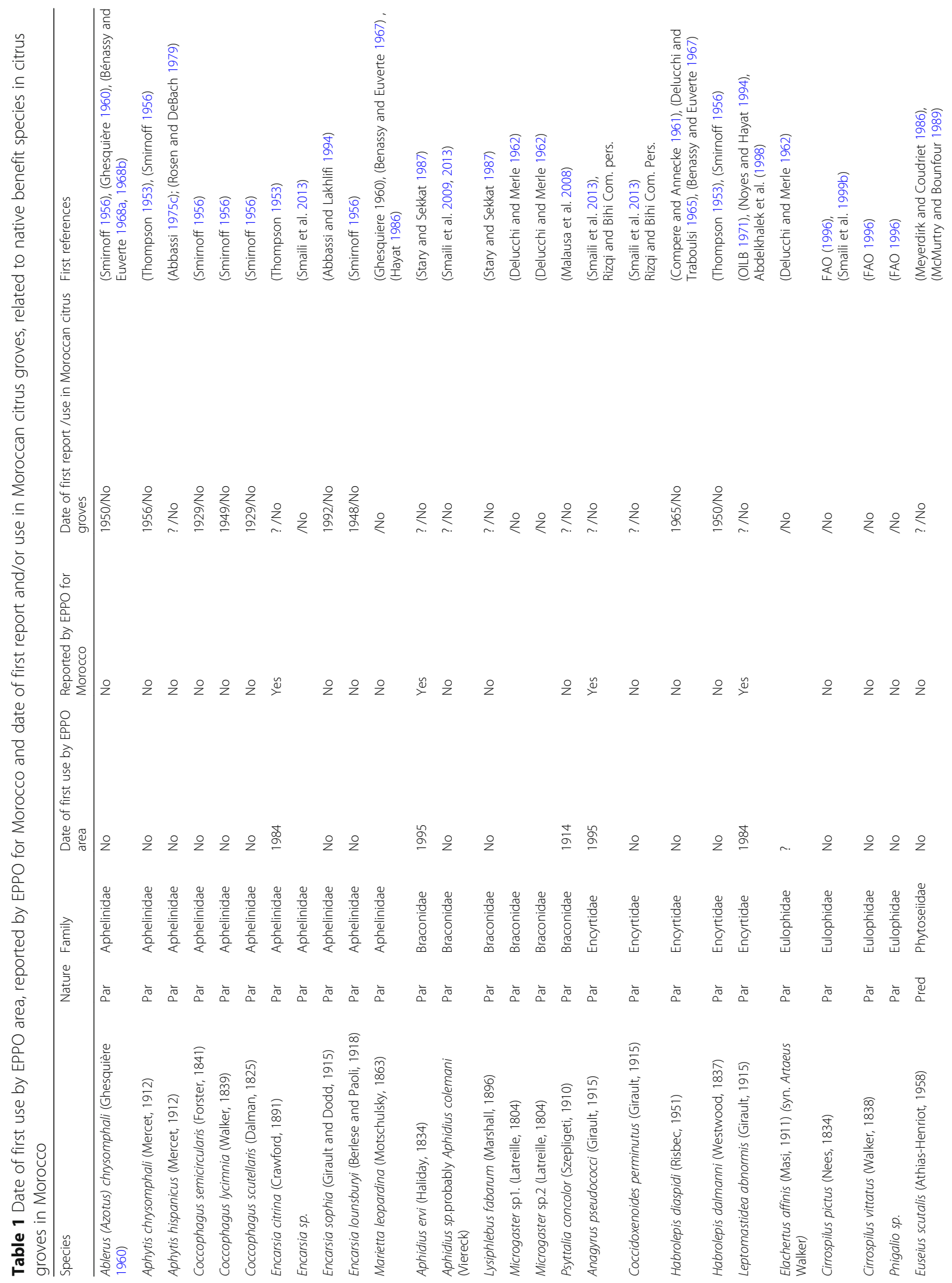




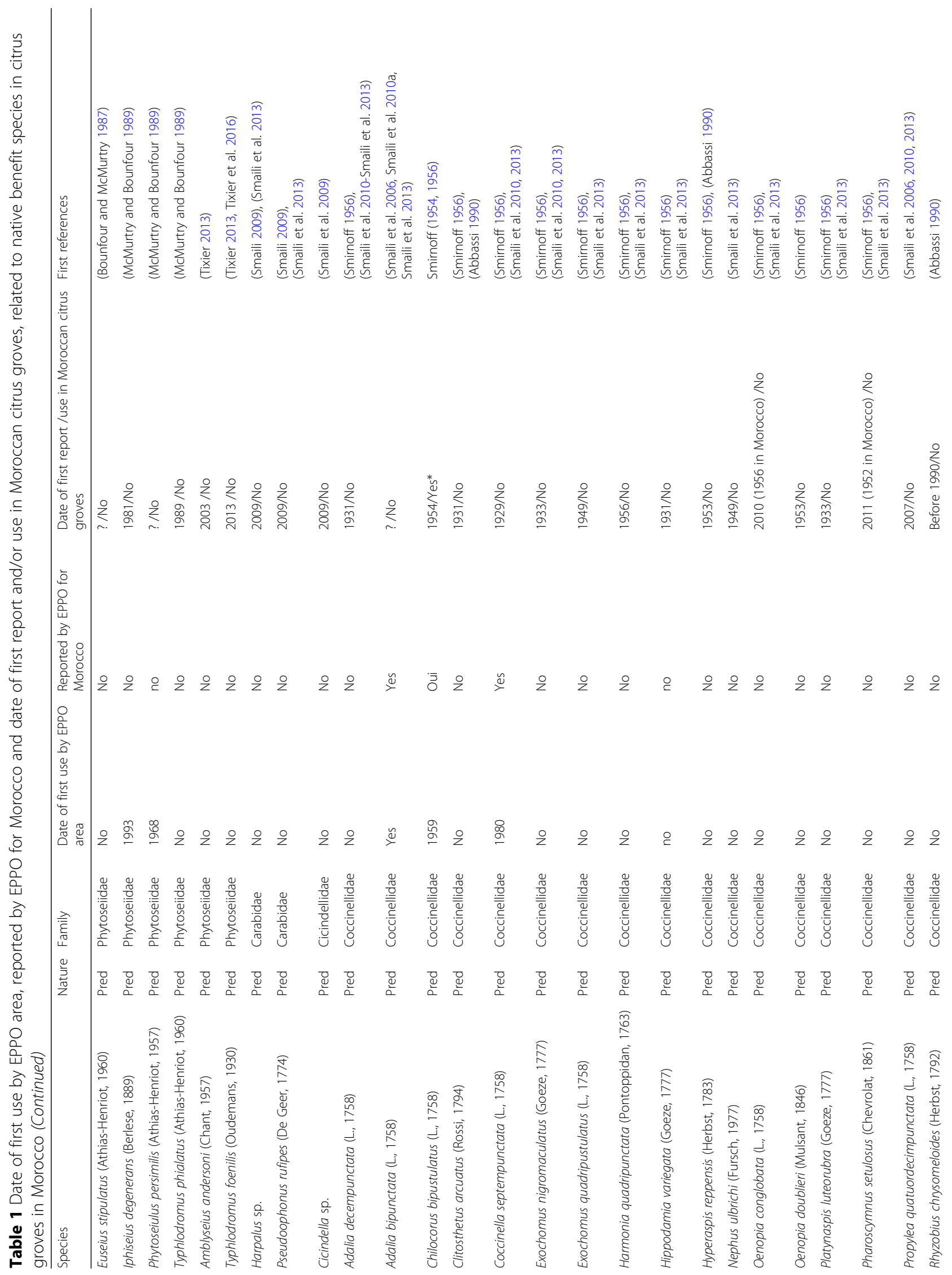




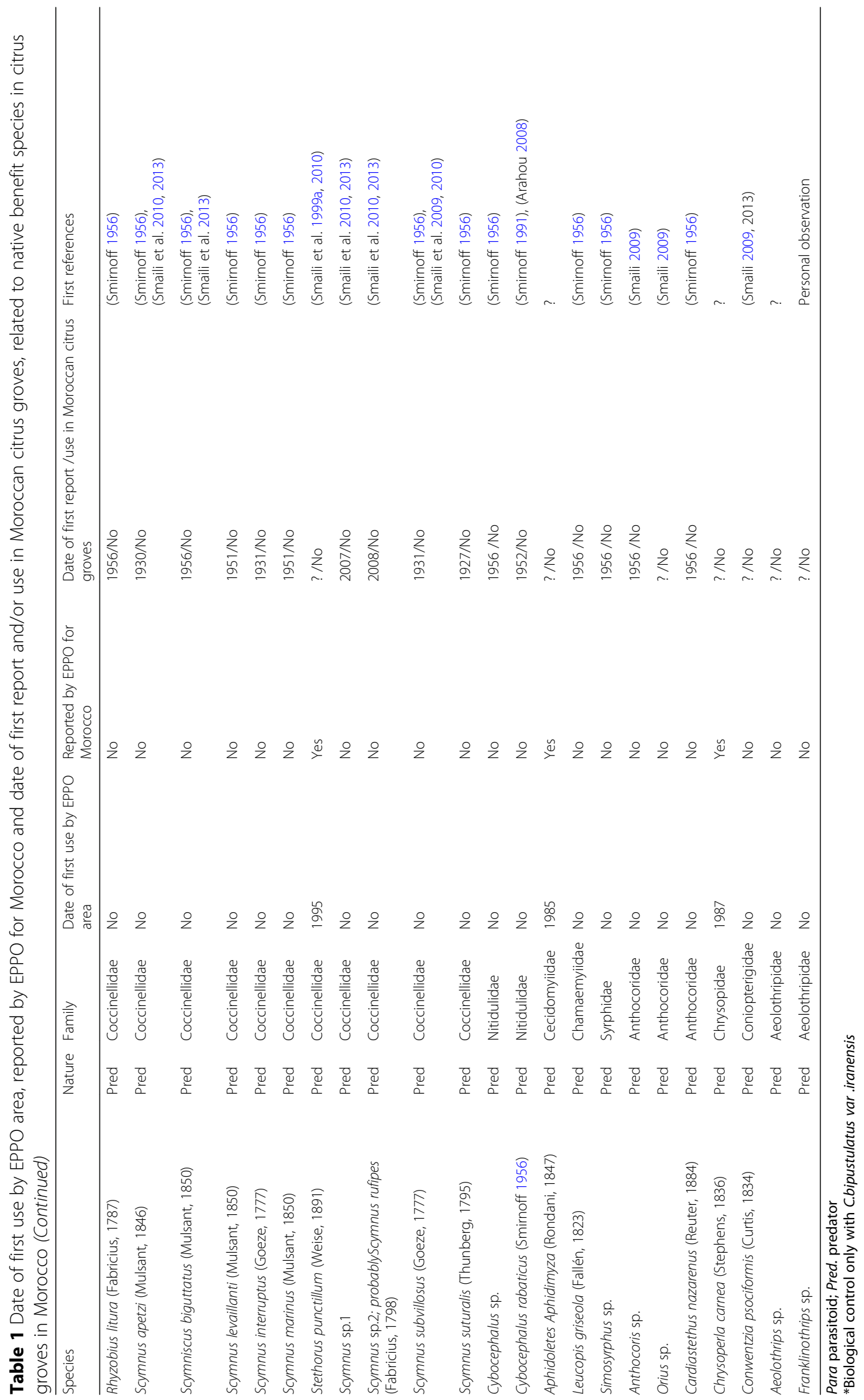




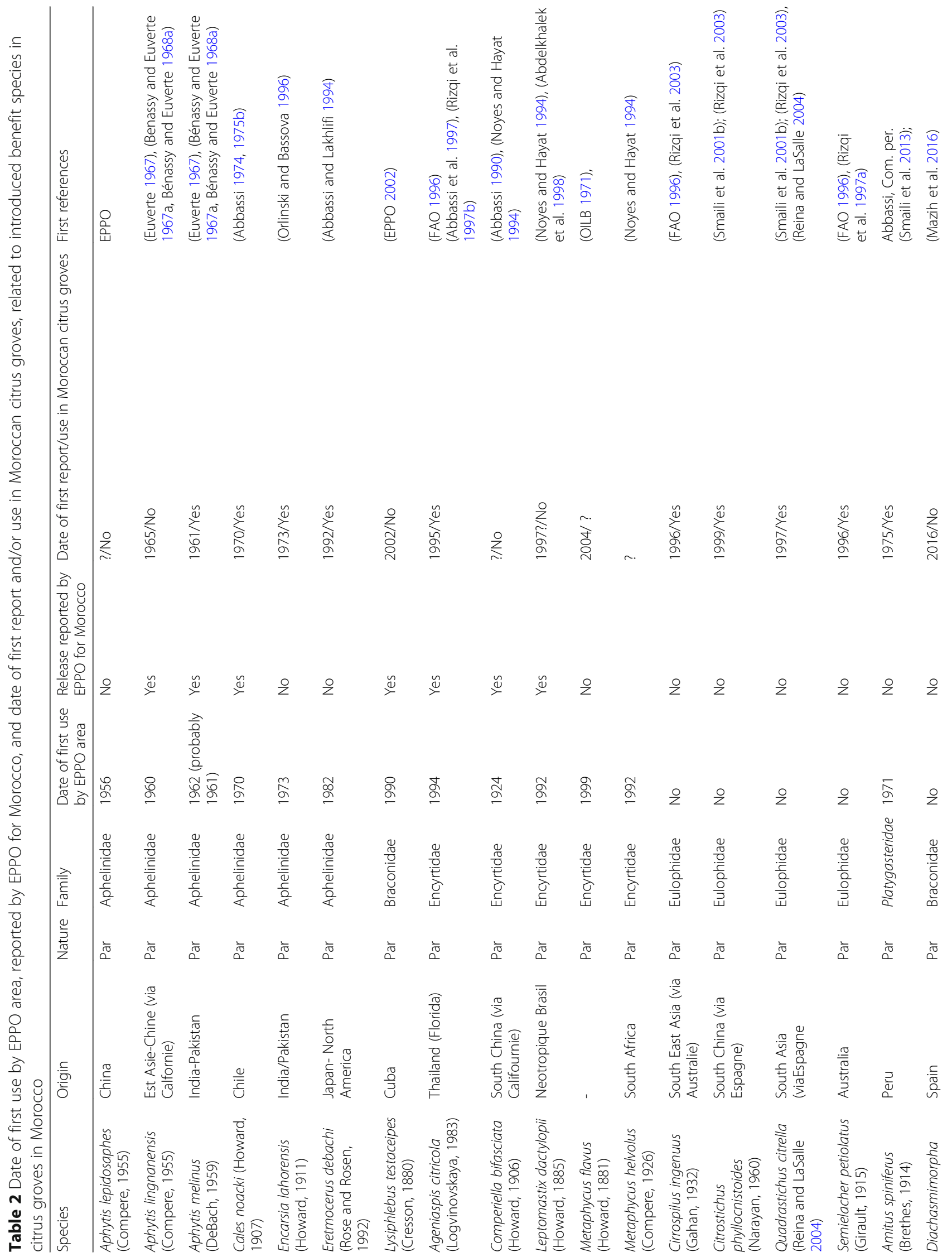




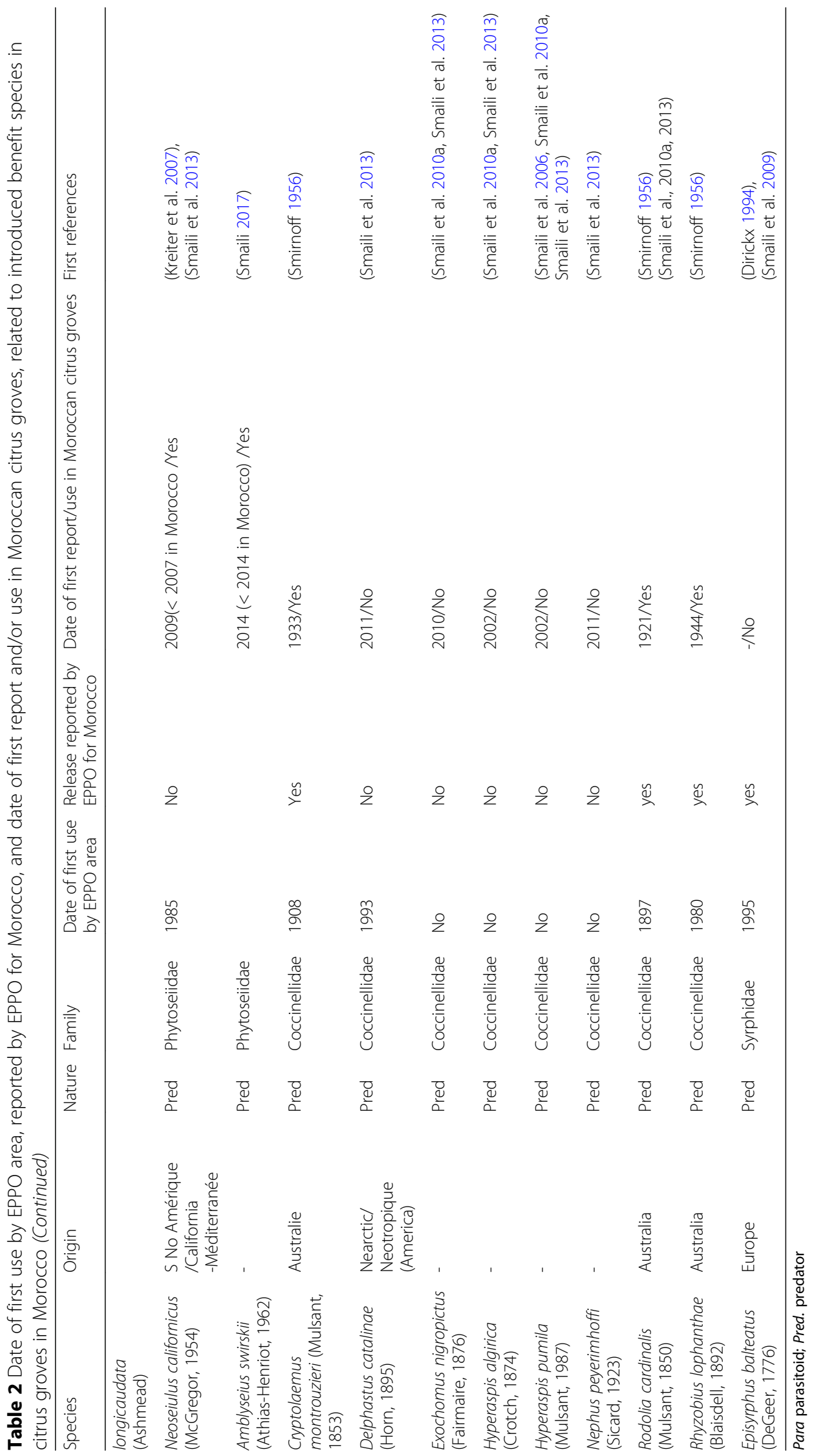




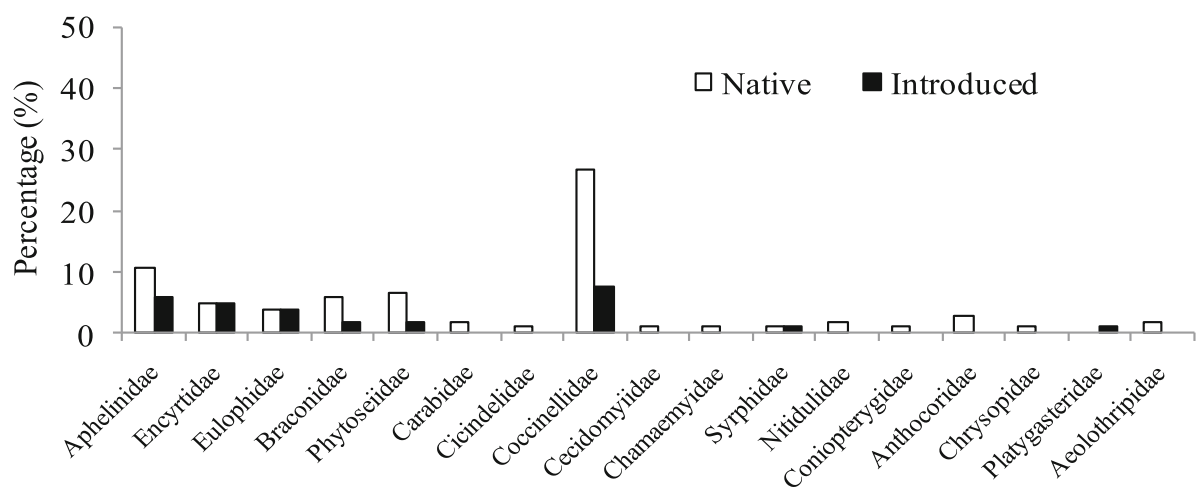

Families

Fig. 1 Percentage of presence (\%) of beneficial species grouped by families in Moroccan citrus orchards $(N=105)$

(20.68\%), Encyrtidae (17.24\%), Eulophidae (13.79\%), Braconidae (6.89\%), Coccinellidae (27.58\%), Phytoseiidae (6.89\%), Syrphidae (3.44\%), and Platygasteridae (3.44\%). The introduced species have been used deliberately to control main target pests in classical biological control reached (68.96\%), mainly for Aphelinidae, Encyrtidae, Eulophidae, Coccinellidae, and Phytoseiidae. The other introduced species have been found accidentally at the citrus trees representing $31.03 \%$. The major voluntarily introduced beneficial species to Morocco came from different origins, especially Spain, South East Asia (via INRA Antibes, France and Florida or California), and Australia. For those introduced accidentally, ladybeetle species are the most noted. In Europe, the majority of beneficial species have been introduced by accident, while a third of the species were intentionally introduced for biological control (Roy et al. 2011). In Morocco, during the period of 1921 to 1944, 3 voluntary introductions of coccinellids were made (Smirnoff 1956; EPPO 2011). Indeed, already in the year 1921, $R$. cardinalis remained the first and the main beneficial insect introduced to the Moroccan citrus orchards to control I. purchasi. Twelve years later, the ladybeetle $C$. montrouzieri was also introduced for biological control of the meal bugs. Then in 1944, there was a third new introduction of $R$. lophanthae to combat the armored scale on citrus, particularly A. aurantii (Smirnoff 1956). During the period of 1961 and 1970, 4 major voluntary introductions were made (Bénassy and Euverte 1968a; Bénassy and Euverte 1968b; Abbassi 1974; Abbassi and Euverte 1974). Three species to control armored scale, A. aurantii and another species Aphelinid species C. noacki, to reduce the whitefly $A$. flocossus. These species were very abundant and important during this period. Since then until the 90 s, very few new introductions were made. This is in case of the parasitoid, A. spiniferus, introduced to control A. floccosus in 1975 (Abbassi 2010). This could be explained by the growing trade, the emergence, the availability, and the efficiency of synthetic chemicals. This is also true for the adoption at this time of the classical chemical control, as an effective control solution. It is important to consider that the new major introductions of parasitoids and/or predator species have been made since the nineties, especially for the purpose of a classical biological control. This is the case of introduced species against citrus leafminer $P$. citrella, as a new pest

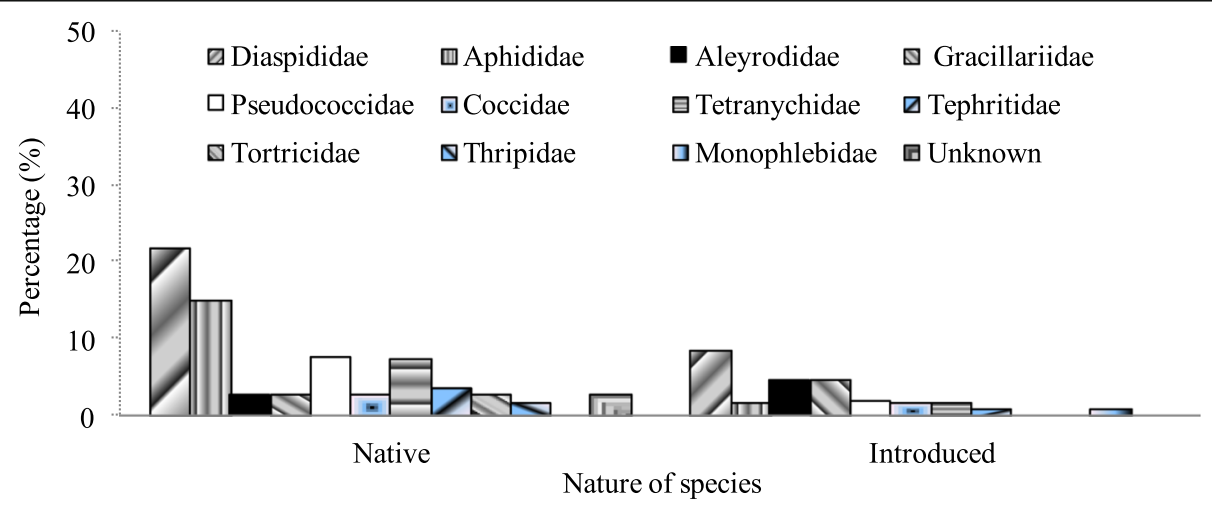

Fig. 2 Percentage of presence (\%) of all beneficial species according to their targeted pests in Moroccan citrus orchards $(N=105)$ 


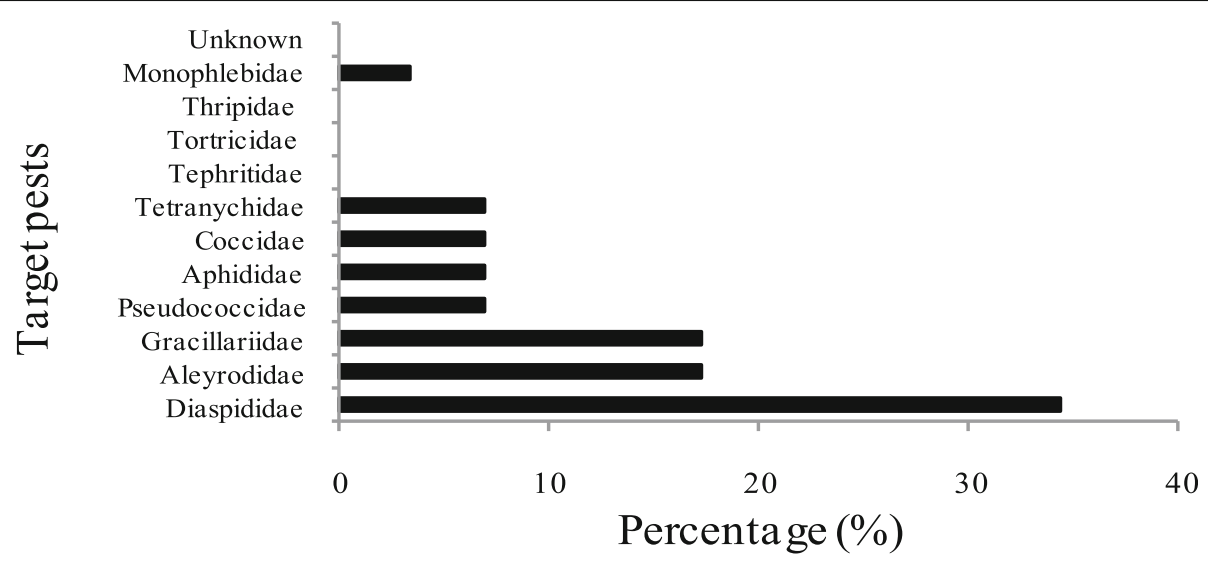

Fig. 3 Percentage of presence (\%) of introduced species according to their targeted pests in Moroccan citrus orchard $(N=29)$

emerging in 1994 in Morocco (Belarbi and Abir 1995). Theses introductions were later coincided with the implementation of integrated pest management program and also the organic agriculture protection in several agricultural sectors in Morocco.

The introduction of the certification procedure and the elimination of several active ingredients from commercial markets in Morocco encouraged more citrus producers to improve their integrated pest management strategy and use the natural enemies in their pest control management. Except the new introduction in citrus orchards, like the predators Neoseiulus californicus (Mc Gregor) (Acari: Phytoseiidae) and Amblyseius swirskii (Athias-Henriot) (Acari: Phytoseiidae) against the oriental mite E. orientalis, no new deliberate introduction after the 2000s has been done to our knowledge (Smaili et al. 2013; Smaili 2017). However, more A.melinus and many other parasitoids and predators were released in citrus groves in the context of the IPM. This is the case for S. puntillum to control spider citrus mite (Nia et al. 2008), R. cadinalis to control I. purchasi (Nafide et al. 2010), and C. decempunctata to control aphids (Smaili et al. 2014). The introduced parasitoid A. melinus remains the beneficial insect released widely in classical biological control in the main Moroccan citrus area (Abbassi 1990, 2010). Other species were newly introduced in the year 2011 but in an accidental way. This is the case of the ladybeetle D. catalinae (Smaili et al. 2013), which is recognized as a potential predators and very effective against whiteflies (Simmons and Legaspi 2004). The efficacy of this predator is currently considered as unknown in Morocco, because the low infestation of citrus whiteflies located alongside the coastal regions in the northwest part of Morocco, except some citrus groves located at Larache, Tazi, and Belkseri area with high infestations of $A$. floccosus during the 3 last years.

Except new introduction of Diachasmimorpha longicaudata (Ashmead) (Hymenoptera: Braconidae) against the Mediterranean fruit fly Ceratitis capitata (Diptera:
Tephritidae), an important pest for Moroccan citrus growers (Smaili et al. 1999a, 2016; Mazih 2015; Mazih et al. 2016; Smaili 2017). It is also true in terms of citrus thrips whitch has a new economic importance on some citrus groves located in the south part of Morocco (Smaili et al. 2018).

The newly introduced species are significant in terms of their positive impact on the economy or the environment, particularly those introduced for biological control objective (Roy et al. 2011; Van Lenteren et al. 2018). The authors reported that a number of recent successes showed how biological control can save agricultural production when pesticides fail or are not available. According to the authors, in some cases, the new introduction may also have a negative impact, because of the interference of this exogenous species with the indigenous. In Morocco, among the all introduced species, no species has been reported to be harmful to this date. In many countries, the introduction of ladybird Harmonia axyridis Pallas (Coleoptera: Coccinellidae), originated from China, known as aphidophagous species that was imported for a biological control against aphids, but recently it has become a harmful insect for native aphidophagous species (Osawa 2011).

\section{Establishment}

Among the introduced species, a high proportion of parasitoids and predator species was established. A part of $79.31 \%$ of all introduced species has been well established after their introduction (and/or released) in citrus groves under the Moroccan conditions. Percentage of establishment of the introduced species grouped in the families are given in Fig. 4. The Encyrtidae, Eulophidae, and Platygasteridae families included few species that have not been established after their releases (less than 4\%). The Eulophidae, Coccinellidae, and Braconidae remained the only families that include introduced species with unknown level of establishment (3.44\%). 


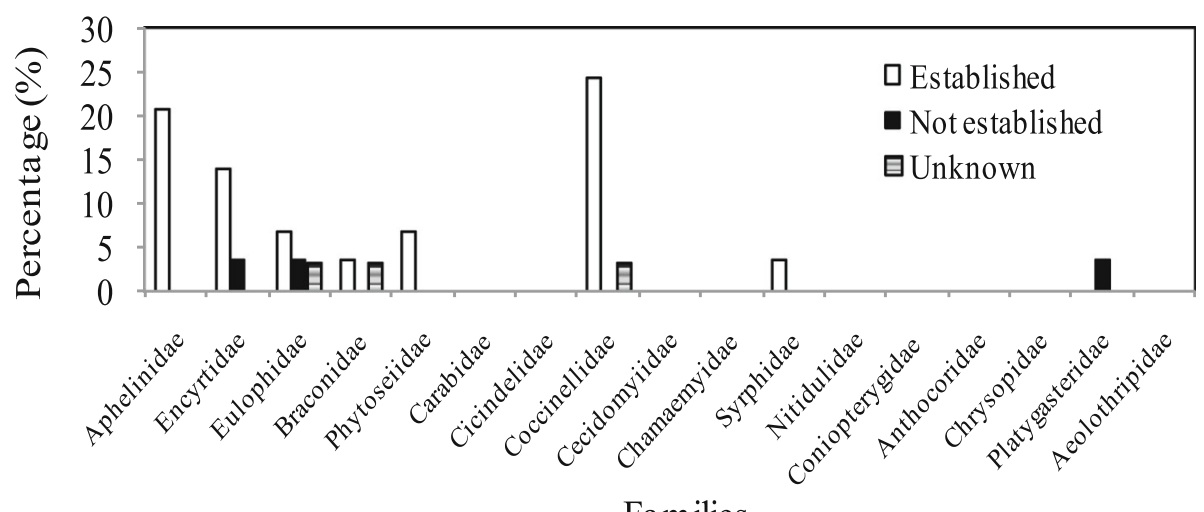

Families

Fig. 4 Percentage of presence (\%) of introduced species grouped by families according to their establishment in Moroccan citrus orchard $(N=29)$

Probably, ecological factors can limit their establishment, a new agro-ecosystem after their introduction. This is the case of A. citricola that did not perform well and failed to reduce leafminer population, after many release in several area of Morocco (Smaili et al. 2001b and Rizqi et al. 2003). Cold winter, and not arid or hot summer, seems to be the main reasons of the failure of this encyrtid in Mediterranean areas (Garcia-Mari et al. 2004). The same authors reported that in Spain, A. citricola was recovered in summer in many release points, reaching nearly $50 \%$ of parasitism and dispersing more than $300 \mathrm{~m}$, but it was not able to overwinter.

\section{Efficacy}

Presence percentage of parasitoids and/or predators species according to their efficacy in controlling main citrus pests is presented in Fig. 5. Among all identified parasitoids and predators species, only few species are effective or partially effective. Among all parasitoids and predators species, $3.80 \%$ is represented as effective species $(0$ and $3.80 \%$ for the native and introduced species, respectively). The percentage of presence of the partially effective species is about $15.23 \%$ (5.71 and $9.52 \%$, respectively). The species that have low efficacy or failed in controlling their target pests represent 50.47 and $27.61 \%$, respectively. It is important to note that $21.90 \%$ (native species), and only 5.71\% (introduced species) are represented by the species which failed to control their targeted pests. Species which efficacy is unknown represent only $2.85 \%$.

For native species, the majority of species is not effective and does not control their target pest. Among the only native species $(N=76)$, the species characterized with low efficacy or failed to control their targeted pests, represent a higher percentage (61.84 and $30.26 \%$, respectively). Conventionally, the native natural enemies are always known by very limited effectiveness against the main pests. Advances will hinge on improved holistic understanding of the ecological roles of this species, particularly coccinellids and their ability to complement other beneficial species (Michaud 2012). This is because conservation biological control should focus on

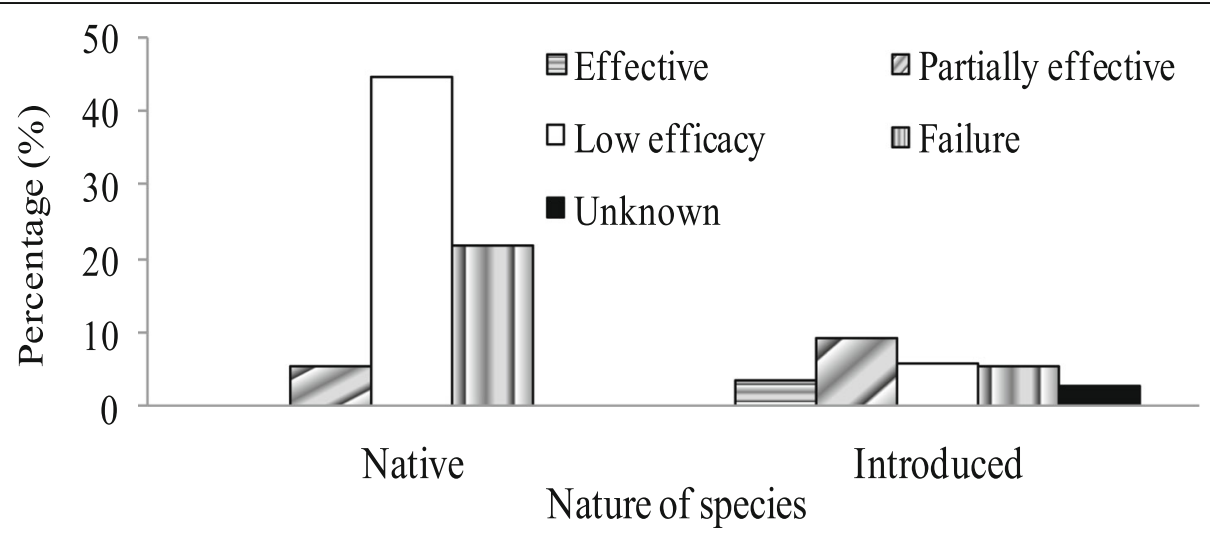

Fig. 5 Percentage of presence (\%) of all beneficial according to their efficacy in Moroccan citrus orchard ( $N=105)$ 
enhancing benefic species arthropod habitats by increasing the natural resources required for survival and reproduction (Botha et al., 2017). The same authors reported that this requires knowledge about the specific requirements of these benefic species, which can only be acquired from species-level data.

Considering all introduced species, few species were represented as effective $(<14 \%)$ or partially effective (the third). Among the all introduced species (for intentionally introduced and unknown), 13.79 and $34.48 \%$ were considered as effective and partially effective, respectively (Fig. 6). Aphelinidae, Encyrtidae, Eulophidae, Coccinellidae, and Phytoseiidae families, include effective species and partially effective. The families like Encyrtidae (3.44\%), Eulophidae (3.44 \%), Platygasteridae (3.44\%), and Coccinellidae (10.34\%) present some introduced species that failed to control their targeted pests. This is the case of the S. petiolatus and C. phyllocnistoides, major parasitoids Eulophidae of P. citrella (Abbassi et al., 1999; Smaili et al. 1999b, 2001; Rizqi et al. 2003 and Abbassi 2010). Species that have failed to control target pests are important. This is the case of $A$. citricola and Q. citrella, 2 introduced parasitoids species of P. citrella (Abbassi et al. 1997; Smaili et al. 2001; Rizqi et al. 2003; Reina and LaSalle 2004). Encyrtidae, Braconidae, and Coccinellidae presented some introduced species that are to control their target pests are considered as unkown $(<4 \%)$.

Considering introduced species used in the term of classical biological control only, 20 and $40 \%$ of the species are considered as very effective or partially effective, respectively; versus the species with low efficacy (15\%) or failed to control their target pests (15\%) (Fig. 7). It is important to note that when the beneficial species are specific, the effectiveness in controlling targeted pests is always very high. In Moroccan conditions, this is true (after repeated release) in the case of parasitoid A. melinus against $A$. aurantii (El Kaoutari et al. 2004; Jebbor et al. 2008; Smaili 2009; Abbassi 2010); for $R$. cardinalis against I. purchasi (Nafid et al., 2010) and for the parasitoids $S$. petiolatus and $C$. phyllocnistoides against $P$. citrella (Rizqi et al. 2003). The importance of this specificity becomes more apparent at every new introduction of the citrus whitefly. This is the case of $C$. noacki against $A$. floccosus; $E$. debachi against $P$. myricae and finally E. lohrensis against D. citri (Abbassi 2010). This specificity has been reported in several countries (Orlinski and Bassova 1996; Argov et al. 1999; Fadamiro et al. 2008). The good plant protection practices consist of the use of specific beneficial insects to control a target pest, based mainly on the phylogenetic knowledge of the parasitoid and its host (Malausa et al. 2008).

\section{Parasitoids and/or predators in Morocco in relation with EPPO database}

Further information on parasitoids and/or predators species in relation to the EPPO database, like date reported; date reported in Morocco; and first references to Morocco are shown in Tables 1 and 2. Some of these introduced parasitoids and/or predators and their uses in biological control were not mentioned by many international scientist web-database. This is the case of $E$. nigropictus identified during 2010 or N. peyerimhoffi and D. catalinae mentioned in 2011 (Smaili et al. 2013). It is the same for database of EPPO, particularly for old introductions of natural enemies (e.g., A. spiniferus and $Q$. citrella) and new introduction (e.g., N. californicus and A. swirskii) (Smaili 2017). This could probably be explained by the scarcity of their population and their low impact on the target pests (low importance), and maybe also the absence of international publications mentioning their impact on main citrus pests in Morocco.

\section{Conclusion}

Among the beneficial insects (parasitoids and/or predators) identified in citrus groves of Morocco, only a small fraction of the introduced species found, attack armored scale and aphids. Considering only introduced species used in classical biological control context, many species

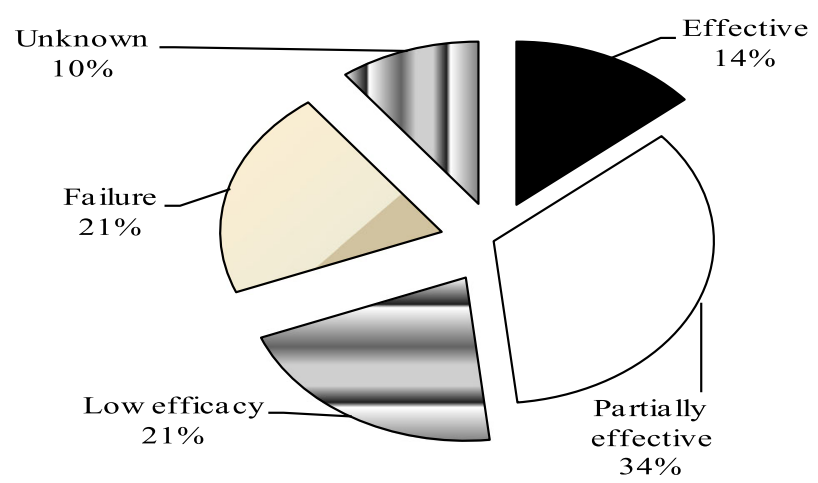

- Effective

$\square$ Partially effective

$\boxminus$ Low efficacy

$\square$ Failure

四 Unknown 


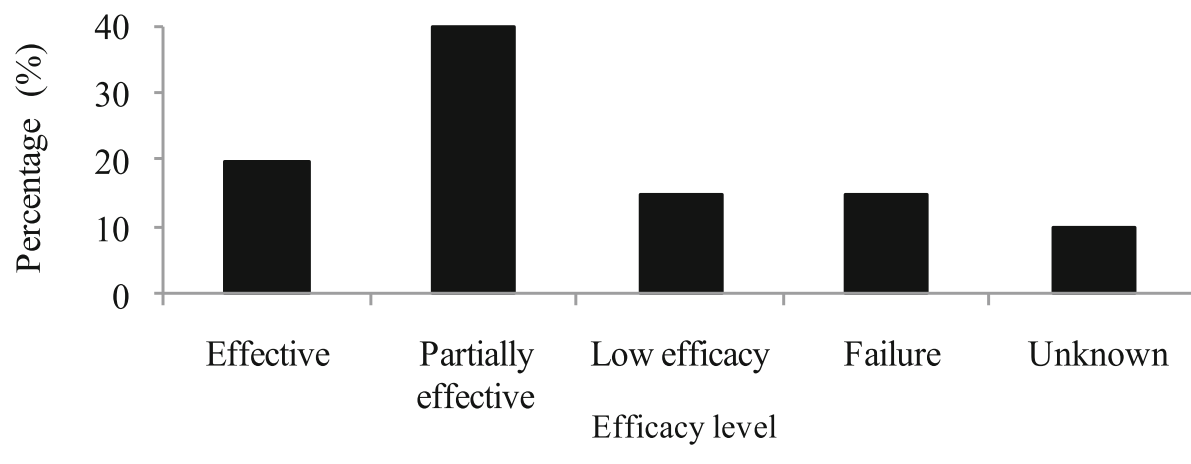

Fig. 7 Efficacy level of introduced species used in term of classical biological control only in Moroccan citrus orchard $(N=20)$

are considered effective or partially effective. This review article may facilitate future investigations on parasitoids and predators species to increase their potential in citrus orchards and to enhance the role of biological control agent (e.g., augmentative biological control) and the integrated pest management services, particularly for citrus in the Mediterranean regions.

\section{Abbreviations}

Ha: Hectare; ASPAM: Moroccan Association of Citrus producers; IPM: Integrated pest managmement; USA: United States of America; INRA: National Agricultural Research Institute; e.g.: Example; N: Total number; Para:: Parasitoid; Pred.: Predator

\section{Acknowledgements}

We are grateful to Dr. Patrick L'Homme (ICARDA, Rabat, Morocco) for his useful comments on an early draft of this manuscript. We thank Editor and two anonymous reviewers for evaluation, comments, and improving the manuscript. Thanks to citrus producers with providing field sites for allowing us to sample in their citrus orchards.

\section{Authors' contributions}

SMC: Conceptualization, data curation, monitoring-compilation-investigation, methodology, interpretation of data; writing-original draft, writing-reviewediting, supervision, and critical revision of the manuscript for important intellectual content. BJA: Methodology, interpretation of data; investigation, writing-review-editing, and critical revision of the manuscript for important intellectual content. BA: Methodology, interpretation of data, supervision; interpretation of data; investigation, writing-review-editing, and critical revision of the manuscript for important intellectual content. All authors read and approved the final manuscript.

\section{Funding}

This study was funded by the National Agricultural Research Institute INRAMorocco (Citrus project: Axe 3; Regional Agricultural Research Center of Kenitra).

\section{Availability of data and materials}

The data and material of this manuscript are available on reasonable request.

\section{Ethics approval and consent to participate}

We agree to all concerned regulations. This article does not contain any studies with human participants or animals or human tissue.

\section{Consent for publication}

We agree to publish this scientific paper at the EJBPC. The manuscript has not been published in completely or in part elsewhere.

\section{Competing interests}

The authors declare that they have no competing interests.

\section{Author details}

${ }^{1}$ Reasearch Unit of Plant Protection, Regional Center for Agricultural Research of Kenitra, National Agricultural Research Institute, Box: 257, Kenitra, Morocco. ${ }^{2}$ Unit of Agricultural Zoology, National School of Agricultural, S/40, Meknes, Morocco. ${ }^{3}$ Sciences Faculty, Department of Biology, University Moulay Ismail, Meknes, Morocco.

Received: 10 October 2019 Accepted: 25 March 2020 Published online: 30 April 2020

\section{References}

Abbassi M (1974) Présence au Maroc d'une nouvelle espèce d'aleurode, Aleurothrixus floccosus Marsk. (Homoptera: Aleurodidae): Ennemis naturels, mesures de lutte. Al Awamia 51:1-8

Abbassi M (1975a) $2^{\text {ème }}$ note sur l'efficacité et l'acclimatation d'Aphytis melinus DeBach au Maroc. Ann Institut Natl Agronomie 5(6):7-17

Abbassi M (1975b) Notes bio-écologiques sur Parlatoria pergandii Comstcok (Homoptera : Diaspididae) au Maroc. Fruits 30(3):179-184

Abbassi M (1975c) Notes bio-écologiques sur Parlatoria pergandei Comstock (Homoptera :. Coccidae) au Maroc. Bull OILB 5:179-184

Abbassi M (1980) Recherche sur deux homoptères fixés des citrus, Aonidiella aurantii (Mask.) (Homoptera:Diaspididae) et Aleurothrixus floccosus Maskell (Homoptera : Aleurodidae). C Rech Agr 35:1-168

Abbassi M (1990) Contribution à la lutte biologique contre les homoptères, ravageurs des citrus au Maroc. Doctoral thesis, Faculté des Sciences Agronomiques de Gembloux, Gembloux, Belgique

Abbassi M (2010) New pests in Morocco and their natural enemies (1970-2010). In: Abstracts of the meeting of the working group on integrated control in citrus Fruit crops, Agadir (Morocco), 1-3 March 2010

Abbassi M, Euverte G (1974) Etude de l'efficacité et de l'acclimatation d'Aphytis melinus De Bach au Maroc. Bull OIBC 3:159-168

Abbassi M, Lakhlifi M (1994) Population dynamics of the Japanese whitelfy, Prabemisia myricae Kuw. (Homoptera: Aleyrodidae) on citrus in Morocco. In: Abstracts of the $V$ Arab Congress of Plant Protection, Fez (Morocco), $27^{\text {th }}$ November - $2^{\text {nd }}$ December1994

Abbassi M, Nia M, Rizqui A, Zemzami M, Nadori EB (1997) Rearing, release and acclimatation of Agenaspis citricola Logv. In: Abstract of the VI Arab Congress of Plant Protection, Beirut (Lebanon), 27-31 October1997

Abbassi M, Harchaoui L, Rizqi A, Nadori EB, Nia M (1999) Biological control against the citrus leafminer Phyllocnistis citrella Stainton (Lepidoptera: Gracillariidae). Paper presented at the $V$ International conference on Pests in agriculture, part 3, Montpellier (France), 7-9 December. 1999

Abdelkhalek L, Afellah M, Smaili MC (1998) Biologie et lutte biologique contre Planococcus citri R. (Homoptera: Pseudococcidae) sur agrumes dans la région du Loukkos au Maroc. Med Fac. Landbouww 63/2b : 483-488

Arahou M (2008) Catalogue de l'entomofaune du Chêne vert du Moyen Atlas. Documents de I'Institut Scientifique 22:1-39

Argov Y, Rössler Y, Voet H, Rosen D (1999) Spatial dispersion and sampling of citrus whitefly Dialeurodes citri, for control decisions in a citrus orchard. Agr Forest Entomol 1(4):305-318

ASPAM (2018) Rapport d'activités du conseil d'administration de l'Association des producteurs d'agrumes du Maroc, Casablanca, Maroc 
Belarbi M, Abir M (1995) La mineuse des agrumes (Phyllocnistis citrella Stainton (Lepidoptera: Phyllocnistidae). Paper presented at the proceeding de I'Association Marocaine de Protection des Plantes, Rabat (Maroc), 14-55 Mars 1995

Bénassy C, Euverte G (1967) Perspectives nouvelles dans la lutte contre Aonidiella aurantii au Maroc (Homoptera: Diaspididae). Entomophaga 12(5):449-459

Bénassy C, Euverte G (1968a) The first use of biological control against Aonidiella aurantii in Morocco. Al Awamia 21:19-25

Bénassy C, Euverte G (1968b) Test of the practical use of biological control against the California scale (Aonidiella aurantii) in Morocco. Al Awamia 28:160

Benziane T (2003) De la lutte dirigée à la lutte intégrée contre les principaux ravageurs en vergers d agrumes au Maroc : cas de la région du Gharb. Doctoral thesis. Université Moulay Ismaïl, Meknès, Maroc

Bonsignore CP, Vacante V (2012) Natural enemies. In: Vacante V, Gerson U (eds) Integrated Control of Citrus Pests in the Mediterranean Region. Bentham Science Publishers, Sharjah (United Arab Emirates)

Botha M, Stefan J, Siebert SJ, Berg JVD, Ellis S, Greyvenstein BM (2017) Diversity patterns of selected predaceous arthropod groups in maize fields and margins in South African Highveld grassland. Agri Forest Entomol 20(4). https://doi.org/10.1111/afe.12277

Bounfour M, McMurtry M (1987) Biology and ecology of Euseius scutalis (AthiasHenriot) (Acarina: Phytoseiidae). Hilgardia 55(5):23

Boutaleb JA, El Hardouni I (2010) Monitoring of the California red scale Aonidiella aurantii (Maskell); the Tetranychid mites and their natural enemies on citrus fruits in the Gharb area (Morocco). In: Abstract of the working group on integrated control in citrus Fruit crops, Agadir (Morocco), 1-3 March 2010

Compere H, Annecke DP (1961) Descriptions of parasitic Hymenoptera and comments (Hymenopt: Aphelinidae, Encyrtidae, Eulophidae). J Entomol Soc South Africa 24:17-71

Delucchi V, Traboulsi R (1965) Habrolepis fanari sp.n (Chalc: Encyrtidae), a parasite of Chrysomphalus ficus Ashmead in North Africa and the middle East (Algeria, Egypt \& the Lebanon) and previously confused with H. pascuorum Merc. and H. dalmanni (Westw.). Ann Soc Entomol Fr 1(2):495

Delucchi VL (1963) La lutte biologique contre les insectes : Compte Rendu au Gouvernement du Maroc. FAO., Rome, Italy Work document n 1646

Delucchi VL, Merle L (1962) La tordeuse de l'œillet, Cacoecia pronubana Huebner (Lepidoptera : Tortricidae) ravageur peu connu des agrumes. Al Awamia 3:79-86

Delucchi VL, Merle L (1963) Un acarien nuisible aux agrumes au Maroc Hemitarsonemus latus Banks (Acarina : Tarsonemidae). Al Awamia 6:17-29

Dirickx HG (1994) Atlas des Diptères syrphides de la région méditerranéenne. Document de Travail. Bull Inst R Sci Nat Belg 75:1-314

El Kaoutari I, Guirrou Z, Chemseddine M, Boumezzough A (2004) Rôle d'Aphytis melinus (DeBach) dans le contrôle naturel d'Aonidiella aurantii (Maskell) en verger d'agrumes au Maroc. Fruit 59(3):169-179

EPPO (2002) Safe use of biological control PM 6/3: List of biological control agents widely used in the EPPO region. Bull OEPP / EPPO 32(2): 447-61

EPPO (2011) EPPO standards on safe use of biological control PM 6/3 -version. 2011. List of biological control agents widely used in the EPPO region. http:// archives.eppo.org/EPPOStandards/. Accessed 30 July 2011

Euverte G (1967) L'insctarium de lutte biologique, production massive d'Aphytis, parasites de cochenilles. Al Awamia 23:59-100

Fadamiro HY, Xiao Y, Hargroder T, Nesbitt M, Umeh V, Childers CC (2008) Seasonal occurrence of key arthropod pests and associated natural enemies in Alabama Satsuma citrus. Environ Entomol 37(2):555-567

FAO (1996) Report of the workshop on citrus leafminer (Phyllocnistis citrella) and its control in the near east. Food and Agricultural. Organisation of the United Nations, Regional Office for the Near East, Cairo, Egypt Work Document 96-34

Garcia-Mari F, Vercher R, Costa-Comelles J, Marzal C, Villalba M (2004) Establishment of Citrostichus phyllocnistoides (Hymenoptera: Eulophidae) as a biological control agent for the citrus leafminer Phyllocnistis citrella (Lepidoptera: Gracillariidae) in Spain. Biol Control 29:215-226

Ghesquière J (1960) Description de deux Aphelinidae récoltés au Maroc (Hymenoptera: Chalcidoidea). Bull Inst R Sci Nat Belg 36:1-10

Hajek AE, Eilenberg J (eds) (2018) Natural enemies: an introduction to biological control. Second edition. Cambridge Univ Press, Cambridge

Hayat M (1986) Notes on some species of Marietta (Hymenoptera: Aphelinidae), with a key to world species. Colemania 2:1-18

Jacas JA, Urbaneja A, Vinuela E (2006) History and future of introduction of exotic arthropod biological control agents in Spain: a dilemma? BioControl 51(1):130
Jebbor Y, Abbassi M, Nia M (2008) Activité d'Aphytis melinus (DeBach), (Hymenoptera : Aphelinidae) et de Comperiella bifascita (Howard), (Hymenoptera, Encyrtidae) sur Pou de Californie. Paper presented at the symposium "Symposium Méditerranéen sur la Protection Phytosanitaire des Agrumes", Rabat (Maroc), 9-11 Juin 2008.

Kreiter S, Tixier MS, Allam L (2007) The diversity of phytoseiid mite communities in the Maghreb comparisons with the fauna of one of the Canary Islands. J Egypt Soc Parasitol 37:381-394

Malausa JC, Rabasse JM, Kreiter P (2008) Les insectes entomophages d'intérêt agricole acclimatés en France métropolitaine depuis le début du 20 ème siècle. Bull EPPO 38:136-146

Mazih A (2015) Status of citrus IPM in the Southern Mediterranean Basin Morocco, North Africa. Acta Hortic 1065:1097-1103

Mazih A, Elaini R, Dali H, Lahmidi K, Elaadama M (2016) Integrated pest management of key insect pests in organic citrus orchard: emphasizing Mediterranean fruit fly and California red scale. In: Abstracts of the International Citrus Congress, Foz do Iguacu (Brazil), 18-23 September 2016.

McMurtry JA, Bounfour M (1989) Phytoseiid mites of Morocco, with descriptions of two new species and notes on the genera Kuzinellus, Typhloctonus, and Typhlodromus (Acari: Phytoseiidae). Acarologia 30:13-24

Meyerdirk DE, Coudriet DL (1986) Evaluation of two biotypes of Euseius scutalis (Acari: Phytoseiidae) as predators of Bemisia tabaci (Homoptera: Aleyrodidae). J Econ Entomol 79(3):659-663

Michaud JP (2012) Coccinellids in biological control. In: Hodek I, Van-Emden HF, Honek A (eds) ecology and behaviour of the ladybird beetles (Coccinellidae). Blackwell Publishing, Ltd, Chichester

Nafide M, Boutaleb AJ, Mazih A, Rizqi A (2010) Research of substitute products for the control of cottony cushion scale Icerya purchasi Maskell (1878) (Hemiptera : Margarodidae) on citrus in Morocco and role of vedalia beetle Rodolia cardinalis Mulsant (Coleoptera: Coccinellidae). In: Abstracts of the meeting working group "Integrated Control in Citrus Fruit Crops, Agadir (Morocco), 1-3 March

Nia M, Bouchakour M, Hanich M (2008) Utilisation de la coccinelle Stethorus spp. (Coleoptera Coccinellidae) comme moyen de contrôle de Panonychus citri (Acarina: Tetranychidae). Paper presented at the symposium "Symposium Méditérranée sur la Protection Phytosanitaire des Agrumes", Rabat (Maroc), 9 11 Juin

Noyes JS, Hayat M (1994) Oriental mealybug parasitoids of the Anagyrini (Hymenoptera: Encyrtidae). CABI Publishing, Oxon

OILB (1971) Liste d'identification des entomophages. OILB 8:1-21

Orlinski AD, Bassova TV (1996) Biological control of citrus whitefly Dialeurodes citri Ashmead (Homoptera: Aleyrodidae) using Encarsia lahorensis Howard (Hymenoptera: Aphelinidae) in countries of the former USSR. Entomophaga 41:493-503

Osawa N (2011) Ecology of Harmonia axyridis in natural habitats within it's native range. BioControl 56:613-621

Reina P, LaSalle J (2004) Two new species of Quadrastichus Girault (Hymenoptera: Eulophidae): parasitoids of the leafminers Phyllocnistis citrella Stainton (Lepidoptera: Gracillariidae) and Liriomyza trifolii (Burgess) (Diptera: Agromyzidae). J Hymenopt Res 13(1):108

Rizqi A, Abbassi M, Nadori EB, Nia M (1997a) Elevage de Semielacher petiolatus parasitoide de la mineuse des agrumes, Phyllocnistis citrella. Paper prsensented at thecongresse "III Congres de I'Association Marocaine de la Protection des Plantes", (Maroc), 23-24 Décembre 1997

Rizqi A, Nadori EB, Abbassi M, Nia M (1997b) Comparaison de trois méthodes d'élevage de Ageniaspis citricola Logvinovska (Hymenoptera : Encyrtidae). Paper prsensented at thecongresse "III Congres de l'Association Marocaine de la Protection des Plantes", (Maroc), 23-24 Décembre 1997.

Rizqi A, Nia M, Abbassi M, Rochd A (2003) Establishment of exotic parasitoides of citrus leafminer Phyllocnistis citrella in citrus groves in Morocco. IOBC Bull 26:1-6

Rosen D, DeBach P (1979) Species of Aphytis of the world (Hymenoptera: Aphelinidae). Ser Entomol 17:392

Roy EH, Roy DB, Roques A (2011) Inventory of terrestrial alien arthropod predators and parasites established in Europe. BioControl 56:477-504

Simmons AM, Legaspi JC (2004) Survival and predation of Delphastus catalinae (Coleoptera: Coccinellidae), a predator of whiteflies (Homoptera: Aleyrodidae), after exposure to a range of constant temperatures. Environ Entomol 33(4):839-843

Smaili C, Afellah M, Zrida L, Aarab A (1999a) Trapping and evaluation of the bait spray to control Medfly in citrus in Gharb area (Morocco). Med Fac. Landboww 64(3a):69-175 
Smaili C, Affellah M, Aarab A, Zrida L (1999b) Biology and ecology of leafminer and evaluation of parasitoids in Clementine in the Gharb area (Morocco). Med Fac . Landbouww. 64/3: 121-131

Smaili C, Wadjinny J, Fursch H (2006) Contribution à la connaissance des espèces et variants des coccinelles (Coleoptera: Coccinellidae) associées aux agrumes dans les régions du Gharb et du Loukkos. Paper prsesented at the Congress "VI Congrès de I'Association Marocaine de la Protection des Plantes", Rabat (Maroc), 29-30 Novembre 200

Smaili MC (2009) Développement de nouvelles stratégies de lutte contre les principaux ravageurs des agrumes dans la région du Gharb: Impact sur la lutte intégrée. Mémoire de Recherche. National Institute for Agricultural Research, Rabat (Morocco)

Smaili MC (2017) Current pest status and the integrated pest management strategy in the citrus groves in Morocco. In: Abstracts of the IOBC citrus working group meeting on citrus pests, diseases and weeds, Valencia (Spain), 25-27 September 2017

Smaili MC, Abbassi M, Boutaleb JA, Blenzar A (2013) Richesse spécifique des ennemis naturels associés aux vergers d'agrumes au Maroc: Intérêt et implication pour la lutte biologique. Bull EPPO 43(1):155-166

Smaili MC, Afellah M, Aarab A (2001) Biologie, écologie et lutte biologique contre Phyllocnistis citrella Stain. sur clémentinier dans la région du Gharb. In : Abstracts of the "I Coll de l'Agriculture : Développement de l'agriculture et de la recherche agronomique dans la région Gharb; Bilan et perspectives", Kénitra (Maroc), 23-24 July 2001

Smaili MC, Bakri A, Gaboune F, Bouharroud R, Blenzar A (2016) Compararison of the effect of spinosad, kaolin and protein bait spray on Ceratitis capitata (Diptera: Tephritidae) in citrus orchards in the Gharb (Morocco). Int J Res Agr Sci 3(4):197-205

Smaili MC, Benyahia H (2018) Nouvelle cicadelle Penthimiola bella sur l'avocatier au Maroc: Une autre menace potentielle pour l'agrumiculture. Agriculture du Maghreb 115:86-87

Smaili MC, Benyahia H, Kabbage T (2018) Invasion des populations du thrips Pezothrips kellyanus (Thysanoptera: Thripidae) sur différentes variétés d'agrumes dans la région du Souss-Massa. Agriculture du Maghreb 114:82-85

Smaili MC, Blenzar A, Boutaleb AJ (2009) Etude prospective de la fondation, de l'immigration et des facteurs de mortalité des colonies de pucerons noirs de I'oranger Toxoptera aurantii Boyer de Fonscolombe (Hemiptera: Aphididae) au nord du Gharb. Int J Mediterr Ecol 35:5-18

Smaili MC, Blenzar A, Fursch H (2010) First record of new species and phenotypes of ladybird (Coleoptera: Coccinellidae) in citrus orchards in Morocco. Faunistic Entomology 62(3):103-107

Smaili MC, El Ghadraoui L, Gaboun F, Benkirane R, Blenzar A (2014) Impact of some alternative methods to chemical control in controlling aphids (Hemiptera : Sternorrhyncha) and their side effects on natural enemies on young citrus Moroccan groves. Phytoparasitica 42:421-436

Smirnoff W (1954) Parasites et prédateurs de cochenilles. Terre Marocaine 279:288-291 Smirnoff W (1956) Observations sur les prédateurs et parasites des cochenilles nuisibles du Maroc et sur leurs ennemis. Service de la défense des végétauxTravaux originaux 11: 1-60

Smirnoff W (1991) Entomologie générale: influence des traitements anti-acridiens sur l'entomofaune de la vallée du Sous (Maroc). In: UPELF-UREF (eds.) Nouveaux acaricides et perspectives. Présentation de la lutte biologique et alternative; la lutte anti-acaridienne. John Libbey Eurotext, Paris

Stary P, Sekkat A (1987) Parasitoids (Hym.: Aphidiidae) of aphid pests in Morocco. Ann Soc Entomol Fr 23:145-149

Thompson WR (1953) A catalogue of the parasites and predators of insect pests. Section 2. Host parasite catalogue. Part 2. Hosts of the Hymenoptera (Agaonidae to Braconidae). Commonwealth Institute of Biological Control, Ottawa-Ontario, Canada Working Document 56-08

Tixier MS (2013) Statistical approaches to assess interspecific differences for morphological continuous characters: the case study of the family Phytoseiidae (Acari: Mesostigmata). Zool Scr 42:327-334

Tixier MS, Allam L, Douin M, Kreiter S (2016) Phytoseiidae (Acari: Mesostigmata) of Morocco: new records, descriptions of five new species, re-descriptions of two species, and key for identification. Zootaxa 4067(5):501-551

Van Lenteren JC, Bolchmans K, Kohl J, Ravensberg WJ, Urbaneja A (2018) Biological control using invertebrates and microorganisms: plenty of new opportunities. BioControl 63:39-59

\section{Publisher's Note}

Springer Nature remains neutral with regard to jurisdictional claims in published maps and institutional affiliations.

\section{Submit your manuscript to a SpringerOpen ${ }^{\odot}$ journal and benefit from:}

- Convenient online submission

- Rigorous peer review

- Open access: articles freely available online

- High visibility within the field

- Retaining the copyright to your article

Submit your next manuscript at $\boldsymbol{\nabla}$ springeropen.com 